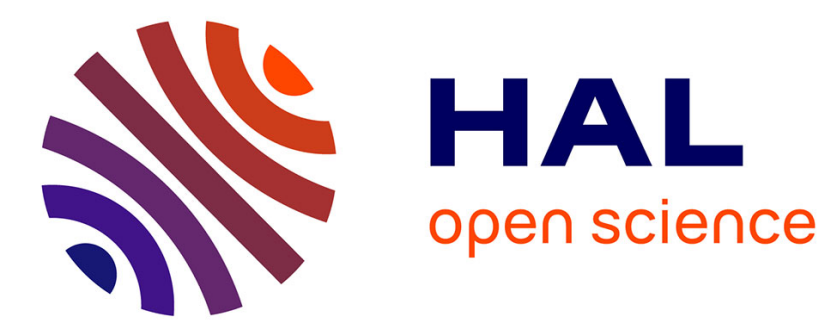

\title{
Population genetic dynamics in the French Guiana region
}

Stéphane Mazières, André Sevin, Sidia Maria Callegari-Jacques, Eric Crubézy, Georges Larrouy, Jean-Michel Dugoujon, Francisco Mauro Salzano

\section{- To cite this version:}

Stéphane Mazières, André Sevin, Sidia Maria Callegari-Jacques, Eric Crubézy, Georges Larrouy, et al. Population genetic dynamics in the French Guiana region. American Journal of Human Biology, 2008, pp.21(1):113-7. hal-00334992

\section{HAL Id: hal-00334992 \\ https://hal.science/hal-00334992}

Submitted on 28 Oct 2008

HAL is a multi-disciplinary open access archive for the deposit and dissemination of scientific research documents, whether they are published or not. The documents may come from teaching and research institutions in France or abroad, or from public or private research centers.
L'archive ouverte pluridisciplinaire HAL, est destinée au dépôt et à la diffusion de documents scientifiques de niveau recherche, publiés ou non, émanant des établissements d'enseignement et de recherche français ou étrangers, des laboratoires publics ou privés. 


\section{Population Genetic Dynamics in the French Guiana Region}

STÉPHANE MAZIÈRES, ${ }^{1 *}$ ANDRÉ SEVIN, ${ }^{1}$ SIDIA M. CALLEGARI-JACQUES, ${ }^{2,3}$ ERIC CRUBÉZY, ${ }^{1}$ GEORGES LARROUY, ${ }^{1}$ JEAN-MICHEL DUGOUJON, ${ }^{1}$ AND FRANCISCO M. SALZANO ${ }^{2}$

${ }^{1}$ Laboratoire d'Anthropobiologie, FRE 2960 CNRS, Toulouse, France

${ }^{2}$ Departamento de Genética, Instituto de Biociências, Universidade Federal do Rio Grande do Sul, 91501-970 Porto Alegre, RS, Brazil

${ }^{3}$ Departamento de Estatística, Instituto de Matemática, Universidade Federal do Rio Grande do Sul, 91501-970 Porto Alegre, RS, Brazil

Number of text pages: 14

34 references, 3 tables, 1 figure, 1 appendix including 14 references

Abbreviated title: POPULATION GENETICS IN FRENCH GUIANA AMERINDIANS

KEY WORDS : French Guiana Amerindians; genetic variability; bottleneck; admixture

Grant sponsors: Direction Régionale des Affaires Culturelles en Guyane, Centre National de la Recherche Scientifique, Ministère de la Culture; Institutos do Milênio and Apoio a Núcleos de Excelência Programs; Conselho Nacional de Desenvolvimento Científico e Tecnológico; Fundação de Amparo à Pesquisa do Estado do Rio Grande do Sul.

${ }^{*}$ Correspondence to: Stéphane Mazières, Laboratoire d'Anthropobiologie CNRS FRE 2960, Faculté de Médecine, 37, allées Jules Guesde, 31000 Toulouse, France. Telephone number: (00 33) 56114 5987; Fax number: (00 33) 56114 5979; E-mail: stephanemazieres@voila.fr 
ABSTRACT Three sets of genetic markers (blood group plus protein polymorphisms, mitochondrial DNA and Y-chromosome) were compared in four French Guiana and one Brazilian Amerindian populations. Spearman's rank correlation coefficient between five gene diversity statistics and historical or present-day population sizes showed significant values, indicating loss of diversity due to population bottlenecks. The three sets of markers furnished distinct admixture estimates, and the blood group plus protein polymorphisms could have overestimated the European contribution to their gene pool. Correspondence analysis distinguished the coastal from the interior populations, possibly reflecting past migration events. 
Blood group and protein loci, nuclear, mitochondrial DNA (mtDNA) and Ychromosome studies have been widely performed in South American Indians (reviews in Salzano and Callegari-Jacques, 1988; Crawford, 1998; Salzano, 2002). These and other results revealed that both geography and linguistics are factors in their microdifferentiation, although their precise relative roles are still being debated.

Agreement between estimates of genetic variation from these different genetic systems has also been investigated (Bortolini et al., 1997, 1998; Battilana et al., 2002). Due to their different patterns of inheritance, mutation rates, and population effective sizes, no clear $a$ priori correspondence between classical and molecular markers is expected in South Amerindian populations (Salzano, 2002; Schurr, 2002). However, the combined use of these genetic markers has proved to be an efficient tool in estimating sex-specific gene flows, such as matings involving mostly non-Amerindian men and Native women (Santos et al., 1999; Mesa et al., 2000; Callegari-Jacques et al., 2003; Marrero et al., 2007).

In two previous papers (Mazières et al., 2007, 2008), we presented the original blood group, protein, mtDNA and Y-chromosome data for five French Guiana and Brazilian Native populations, and discussed their implications for the peopling of the area. In the present study we addressed the following questions: (1) Are historical as well as present population sizes and genetic variabilities correlated? (2) What do classical and molecular markers systems indicate about non-Native admixture? and (3) Do genetic patterns agree with the region's colonization history?

\section{SUBJECTS AND METHODS}

The populations considered were the Emerillon, Kali'na, Palikur and Wayampi of French Guiana, as well as the neighboring Brazilian Apalaí. Data related to their genetic 
variability at the protein, mtDNA, and Y-chromosome levels for total numbers of 719, 262 and 151 individuals respectively were taken from Salzano et al. (1988) and Mazières et al. $(2007,2008)$

Spearman's rank correlation coefficient $\left(\mathrm{r}_{\mathrm{S}}\right)$ was used for the comparison between the demographic and genetic data. Its non-parametric measure of correlation was preferred because it does not require the assumption that the relationship between the variables is linear and it can be used for ordinal variables (Zar, 1999). For this calculation, only the blood group plus protein and the mtDNA results were used, since the $\mathrm{Y}$ chromosome DNA markers are mainly monomorphic in French Guiana Indians (Mazières et al., 2008). The genetic diversity variables displayed there were calculated with ARLEQUIN ver 3.1 (Excoffier et al., 2005). To enlarge the number of groups in the correlation between population sizes and genetic diversity one additional population (Zoró) examined for the same genetic markers (Ward et al., 1996; Salzano et al., 1998) was included in this study. Historical information for that additional group was obtained in Ward et al. (1996) and http://www.iussp.org (Source: Brasil Socioambiental Program, The Socioambiental Institute, University of Campinas).

Blood group and protein data were presented in Mazières et al. (2007) and were pooled in the admixture analyses using the ADMIX95 and ADMIX2 (Chakraborty, 1985) programs. Conveniently, they provide a multiple regression coefficient $\left(\mathrm{R}^{2}\right)$ to test the appropriateness of the admixture model. Parental frequencies were taken from the Porto Alegre databank and can be supplied on request. One of the advantages of this method is the incorporation of sampling and drift factors in the standard errors (Chakraborty, 1986). The mtDNA and Y-chromosome admixture values were obtained directly from the frequencies of continent-specific haplogroups or haplotypes. The A-D mtDNA haplogroups were considered to be of Amerindian (Torroni et al., 1992) and the L2d2 haplotype (the only non-Amerindian) of sub-Saharan origin (Salas et al., 2002) respectively. For the Y-chromosome, the $\mathrm{Y}^{*}$ lineage 
was considered to be of European origin, since it is neither Amerindian nor African continentspecific (Jobling and Tyler-Smith, 2003). Gene frequencies of the classical (allele) and molecular (haplogroup) genetic markers were combined into a three-dimensional correspondence analysis (Ward, 1963) performed with the MVSP v3.1 program (Kovach Computing Services, Anglesey, Wales).

\section{RESULTS}

Table 1 presents population sizes at bottleneck and recent times for the six tribes, while Table 2 displays Spearman's rank correlation coefficients between five genetic diversity statistics and these two demographic parameters. Six Spearman's $r_{s}$ coefficients were significant at the $5 \%$ level. For the six groups the correlations ranged from 0.457 to 0.943 , with an average of 0.617 and 0.806 for the two sets of values. The Palikur data showed deviations from the expected, maybe due to their strict mating reliance on endogamic rules (Grenand and Grenand, 1987). When they are deleted the correlations increase markedly (averages of 0.680 and 0.910 , respectively).

Percentages of non-Amerindian admixture are displayed in Table 3. The high $\mathrm{R}^{2}$ values indicate good fit for the autosome (blood group plus protein) estimates. The three sets of genetic markers showed distinct degrees of efficiency in the detection of non-Native heritage, with the blood group plus protein series almost always showing higher amounts of European admixture. Independently of the system used the Apalaí, however, seem to have almost no non-Amerindian genes; while the Palikur would have just about 5\% such genes, that could be either of European or African origins. The three other tribes would have around $15 \%$ of non-Native DNA, but such component was not detected in the mtDNA and Ychromosome comparisons. The result of the asymmetrical pattern of unions which occurred 
during Colonial times (non-Amerindian men mating with Amerindian women; Salzano and Bortolini, 2002) was observed in the higher number of non-Amerindian ancestry found in the Y-chromosome as opposed to mtDNA among the Kali'na and Palikur.

When all the genetic data are considered in a correspondence analysis (Fig. 1), most of the alleles/haplogroups clustered in a core while the Y-chromosome $\mathrm{Q}^{*}$, mtDNAs A-C, $R h^{*} c D e$ and $P G M I^{* 2}$ as well as the non-Amerindian $\mathrm{Y}$-chromosome $\mathrm{Y}^{*}$ lineage and $G M^{*} 3,5^{*}$ allotype occupied peripheral positions. Axis 1 separated the Wayampi, Emerillon and Palikur from the Apalaí and Kali'na, while axis 2 distinguished the Emerillon. A geographical subdivision is visible on axis 3, where the coastal groups Palikur and Kali'na stand away from the interior Emerillon, Wayampi and Apalaí.

\section{DISCUSSION}

The French Guiana region, including French Guiana and the northern Brazilian State of Amapá, was densely inhabited when the first Europeans arrived, in the $16^{\text {th }}$ century, with about 17 tribes living there in the 18th century (Hurault, 1965; Grenand and Grenand, 1979). Afterwards, first the coastal and then the interior tribes suffered from epidemics due to disease agents to which they were not adapted (Hurault, 1965). French Guiana is presently inhabited by five remnant non-acculturated Native American populations, and close to them live ethnic groups from many parts of the world (Bois et al., 1993), for example the Asiatic Hmong or the African-originated Bushinengue (Price and Price, 2004).

Mann (2005) expressed the opinion that omitting demography could lead to inaccurate interpretations of the history of present-day South Amerindians. Our analysis of the correlations between past and present population sizes and present genetic variability indicated positive values. The more a population suffered from a demographic bottleneck, the 
less genetic variable it presently shows. This is especially true for the Emerillon, as evaluated by all genetic systems studied until now (Mazières et al., 2007, 2008). On the other hand, historical data inform that the Wayampi absorbed residual groups and kidnapped women from tribes of the high Oyapock River at the mid-19th century (Hurault, 1965), while the Apalaí as established by field information, merged with the Wayana at the end of the same century (Ricardo and Gallois, 1983; Salzano et al., 1988). This would bring new biological components, especially for the Wayampi mtDNA, and maintain their variability. In the coastal Kali'na this scenario may have been widened by the occurrence of non-Native components.

Quantitative evaluation of the degree of interethnic admixture in a given population is an important tool for the understanding of its history, and has also practical implications, through admixture mapping, in the localization of disease genes which have different interethnic disease risks (Price et al., 2007). Both the methods of ancestry identification by uniparental continent-specific lineages and the dilution approach which characterizes the autosomal estimates have intrinsic limitations, and therefore it is not surprising to obtain, as was found here (for instance, among the Emerillon and Wayampi) different estimates using these alternative methods. In the present study we suspect that the blood group plus protein markers may be overestimating the degree of European admixture really present, since the values are based on global comparisons between non-specific allele frequency differences between the population considered and putative ancestors. It is also well-known that diversity in the amount of the differences observed between the frequencies of the postulated ancestral gene pools as well as uncertainties about these ancient values may affect the admixture estimates obtained by this method.

A curious finding reported by Mazières et al. (2008) was the presence of the L2d2 mtDNA sequence in two Kali'na subjects. Since this is a very rare haplotype we surveyed all the literature on African or African-derived persons to ascertain its detailed frequency, and the 
results are shown in the Appendix. In Africa only 21 instances of it in 1951 individuals from 47 samples were found (1.1\%), all of them in West Africa. A similar prevalence (1.0\%) was found in African-derived American people. The most probable source of this haplotype in the Kali'na are the Buchinengue (Noir-Marron), and African-derived ethnic group which lives not very far away from them (Price and Price, 2004). It is possible that this sequence may have an unusually high frequency among the Buchinengue, a study worth pursuing.

The combined consideration of all genetic markers tested are in agreement with the history of French Guiana Amerindian colonization (Grenand and Grenand, 1985) in the separation of the two littoral populations (Kali'na, Palikur), which were the first to enter the region, from the interior Emerillon and Wayampi, who migrated later. 


\section{CONCLUSION}

The extreme population reductions suffered by the five tribes considered here were significantly reflected in their genetic background, independently of the system examined. The interethnic gene flow which occurred along the time, however, was differently signalized by the three sets of markers. The two littoral populations can be clearly separated from the interior groups, reflecting the region's past colonization. 


\section{LITERATURE CITED}

Battilana J, Bonatto SL, Freitas LB, Hutz MH, Weimer TA, Callegari-Jacques SM, Batzer MA, Hill K, Hurtado AM, Tsuneto LT, Petzl-Erler ML, Salzano FM. 2002. Alu insertions versus blood group plus protein genetic variability in four Amerindian populations. Ann Hum Biol 29:334-347.

Bois E, de Schutter R, Lopez C, de Sierra X. 1993. Les gens de Guyane. Eléments de compréhension pour une manière d'accueillir l'étranger. Paris: CIMADE.

Bortolini MC, Salzano FM, Zago MA, Silva-Junior WA, Weimer TA. 1997. Genetic variability in two Brazilian ethnic groups: a comparison of mitochondrial and protein data. Am J Phys Anthropol 103:147-156.

Bortolini MC, Baptista C, Callegari-Jacques SM, Weimer TA, Salzano FM. 1998. Diversity in protein, nuclear DNA, and mtDNA in South Amerinds - agreement or discrepancy? Ann Hum Genet 62:133-145.

Callegari-Jacques SM, Grattapaglia D, Salzano FM, Salamoni SP, Crossetti SG, Ferreira ME, Hutz MH. 2003. Historical genetics: spatiotemporal analysis of the formation of the Brazilian population. Am J Hum Biol 15:824-834.

Chakraborty R. 1985. Gene identity in racial hybrids and estimates of admixture. In: Ahuja YR, Neel JV, editors. Genetic microdifferenciation in human and other animal populations. Delhi: Indian Anthropological Association. p 171-180.

Chakraborty R. 1986. Gene admixture in human populations: models and predictions. Yearb Phys Anthropol 29:1-43.

Crawford MH. 1998. The origins of Native Americans. Evidence from anthropological genetics. Cambridge: Cambridge University Press. 
Excoffier L, Laval G, and Schneider S. 2005. Arlequin ver. 3.0: An integrated software package for population genetics data analysis. Evolut Bioinform Online 1: 47-50.

Grenand F, Grenand P. 1979. Les Amérindiens de Guyane française aujourd'hui : éléments de compréhension. Bull Soc Américanistes 66: 361-382.

Grenand P, Grenand F. 1985. La question amérindienne en Guiane française: éléments d'histoire amerindienne. Ethnies 1:11-17; 23-26.

Grenand F, Grenand P. 1987. La côte d'Amapá, de la bouche de l'Amazone à la baie d'Oyapock, à travers la tradition orale palikur. Bol Mus Par Emílio Goeldi, sér Antropol 3:1-78.

Hurault J. 1965. La population des Indiens de Guyane française. Population 20:603-632; 801828 .

Jobling MA, Tyler-Smith C. 2003. The human Y chromosome: an evolutionary marker comes of age. Nat Rev Genet 4:598-612.

Mann CC. 2005. 1491: Nouvelles révélations sur les Amériques avant Christophe Colomb. Paris: Albin Michel.

Marrero AR, Bravi C, Stuart S, Long JC, Pereira das Neves Leite F, Kommers T, Carvalho CM, Pena SD, Ruiz-Linares A, Salzano FM, Bortolini MC. 2007. Pre- and postColumbian gene and cultural continuity: the case of the Gaucho from southern Brazil. Hum Hered 64:160-171.

Mazières S, Sevin A, Bonnet F, Crubezy E, Salzano FM, Larrouy G. 2007. Genetic studies in French Guiana populations: synthesis. Am J Phys Anthropol 132:292-300.

Mazières S, Guitard E, Crubezy E, Dugoujon JM, Bortolini MC, Bonatto SL, Hutz MH, Bois E, Tiouka F, Larrouy G, Salzano FM. 2008. Uniparental (mtDNA, Y-chromosome) polymorphisms in French Guiana and two related populations - implications for the region's colonization. Ann Hum Genet 72:145-156. 
Mesa NR, Mondragon MC, Soto ID, Parra MV, Duque C, Ortiz-Barrientos D, Garcia LF, Velez ID, Bravo ML, Munera JG, Bedoya G, Bortolini MC, Ruiz-Linares A. 2000. Autosomal, mtDNA, and Y-chromosome diversity in Amerinds: pre- and postColumbian patterns of gene flow in South America. Am J Hum Genet 67:1277-1286.

Price AL, Patterson N, Yu F, Cox DR, Waliszewska A, McDonald GJ, Tandon A, Schirmer C, Neubauer J, Bedoya G, Duque C, Villegas A, Bortolini MC, Salzano FM, Gallo C, Mazzotti G, Tello-Ruiz M, Riba L, Aguilar-Salinas CA, Canizales-Quinteros S, Menjivar M, Klitz W, Henderson B, Haiman CA, Winkler C, Tusie-Luna T, RuizLinares A, Reich D. 2007. A genomewide admixture for Latino populations. Am J Hum Genet 80:1024-1036.

Price R, Price S. 2004. Les Marrons. Culture en Guyane. $2^{\text {ème }}$ édition, Cayenne: Vents d'ailleurs.

Ricardo CA, Gallois D. 1983. Povos indígenas no Brasil: 3. Amapá/Norte do Pará. São Paulo: Centro Ecumênico de Documentação e Informação.

Salas A, Richards M, De la Fe T, Lareu M-V, Sobrino B, Sanchez-Diz P, Macaulay V, Carracedo A. 2002. The making of the African mtDNA landscape. Am J Hum Genet $71: 1082-1111$

Salzano FM. 2002. Molecular variability in Amerindians: widespread but uneven information. An Acad Bras Cienc 74:223-263.

Salzano FM, Bortolini MC. 2002. The evolution and genetics of Latin American populations. Cambridge: Cambridge University Press.

Salzano FM, Callegari-Jacques SM. 1988. South American Indians. A case of study in evolution. Oxford: Clarendon Press. 
Salzano FM, Black FL, Callegari-Jacques SM, Santos SE, Weimer TA, Mestriner MA, Pandey JP, Hutz MH, Rieger TT. 1988. Genetic variation within a linguistic group: Apalai-Wayana and other Carib tribes. Am J Phys Anthropol 75:347-356.

Salzano FM, Weimer TA, Franco MHLP, Callegari-Jacques SM, Mestriner MA, Hutz MH, Santos RV, Coimbra C.E.A. Jr. 1998. Protein genetic studies among the Tupi-Mondé Indians of the Brazilian Amazonia. Am J Hum Biol 10:711-722.

Santos SEB, Rodrigues JD, Ribeiro-dos-Santos AK, Zago MA. 1999. Differential contribution of indigenous men and women to the formation of an urban population in the Amazon region as revealed by mtDNA and Y-DNA. Am J Phys Anthropol $109: 175-180$.

Schurr TG. 2002. A molecular anthropological perspective on the peopling of the Americas. Athena Rev 3:62-107.

Torroni A, Schurr TG, Yang CC, Szathmary EJ, Williams RC, Schanfield MS, Troup GA, Knowler WC, Lawrence DN, Weiss KM, Wallace DC. 1992. Native American mitochondrial DNA analysis indicates that the Amerind and the Nadene populations were founded by two independent migrations. Genetics 130:153-162.

Ward RH. 1963. Hierarchical grouping to optimise an objective function. J Am Stat Assoc $58: 236-244$.

Ward RH, Salzano FM, Bonatto SL, Hutz ML, Coimbra CEA Jr, Santos RV. 1996. Mitochondrial DNA polymorphism in three Brazilian Indian tribes. Am J Hum Biol $8: 317-323$.

Zar J. 1999. Biostatistical analysis. 4th ed. Upper Saddle River, NJ: Prentice-Hall. 
Fig. 1. Blood group, mtDNA and Y chromosome correspondence analysis considering the five French Guiana populations. 
TABLE 1. Population sizes at bottleneck and recent times for six Amerindian tribes ${ }^{a}$

\begin{tabular}{|c|c|c|c|c|}
\hline \multirow{2}{*}{ Tribes } & \multicolumn{2}{|l|}{ Nadir } & \multicolumn{2}{|c|}{ When studied } \\
\hline & Population number & Date & Population number & Date \\
\hline Emerillon & 52 & 1953 & 218 & 1985 \\
\hline Palikur & 220 & 1840 & 945 & 1998 \\
\hline Kali'na & 250 & 1848 & 1550 & 1978 \\
\hline Wayampi & 212 & 1947 & 910 & 1994 \\
\hline Apalaí & 280 & 1890 & 280 & 1998 \\
\hline Zoró & 215 & 1990 & 400 & 2000 \\
\hline
\end{tabular}

${ }^{\mathrm{a} S}$ Sources: Grenand and Grenand (1979); Salzano et al. (1988, 1998). 
TABLE 2. Correlation between population sizes at bottleneck and recent times with several estimates of genetic variability ${ }^{a}$

\begin{tabular}{|c|c|c|c|c|}
\hline \multirow{3}{*}{ Genetic diversity variables } & \multicolumn{4}{|c|}{ Spearman's $r_{s}$} \\
\hline & \multicolumn{2}{|c|}{ Population number at nadir } & \multicolumn{2}{|c|}{ Recent population number } \\
\hline & All & $\begin{array}{c}\text { Without the } \\
\text { Palikur }\end{array}$ & All & $\begin{array}{c}\text { Without the } \\
\text { Palikur }\end{array}$ \\
\hline $\mathrm{H}$ & 0.657 & 0.900 & 0.457 & 0.650 \\
\hline $\mathrm{h}$ & 0.714 & 0.850 & 0.743 & 0.900 \\
\hline $\mathrm{D}$ & 0.571 & 0.550 & $0.943^{*}$ & $1.000 *$ \\
\hline $\mathrm{Pw}$ & 0.571 & 0.550 & $0.943^{*}$ & $1.000 *$ \\
\hline$\pi$ & 0.517 & 0.550 & $0.943^{*}$ & $1.000 *$ \\
\hline mean & 0.617 & 0.680 & 0.806 & 0.910 \\
\hline
\end{tabular}

${ }^{a} \mathrm{H}$ : blood group variability; h: mtDNA haplogroup diversity; D: mtDNA haplotype diversity; Pw: number of nucleotide differences per HVS haplotype; $\pi$ : mtDNA nucleotide diversity. Data reported in Ward et al. (1996), Salzano et al. (1998), Mazières et al. (2008) and http://www.iussp.org.

* Six Spearman's rs coefficients were significant. 
TABLE 3. Percentages of non-Indian admixture

\begin{tabular}{|c|c|c|c|c|c|c|}
\hline \multirow{2}{*}{ Tribes } & \multirow{2}{*}{ Systems } & \multirow{2}{*}{ No. systems } & \multicolumn{3}{|c|}{ Parental contribution } & \multirow{2}{*}{$\mathbf{R}^{2}$} \\
\hline & & & Amerindian & African & European & \\
\hline \multirow[t]{3}{*}{ Apalaí } & mtDNA & & 100 & & & \\
\hline & Blood group + protein & 22 & $99.01 \pm 0.25$ & & $0.99 \pm 0.25$ & 0.9999 \\
\hline & Y-chromosome & & 100 & & & \\
\hline \multirow[t]{3}{*}{ Emerillon } & MtDNA & & 100 & & & \\
\hline & Blood group + protein & 20 & $86.37 \pm 5.07$ & & $13.63 \pm 5.07$ & 0.9386 \\
\hline & Y-chromosome & & 100 & & & \\
\hline \multirow[t]{3}{*}{ Kali'na } & mtDNA & & 93.1 & 6.9 & & \\
\hline & Blood group + protein & 13 & $84.96 \pm 0.75$ & & $15.04 \pm 0.75$ & 0.9991 \\
\hline & Y-chromosome & & 81 & 9.4 & 9.6 & \\
\hline \multirow[t]{3}{*}{ Palikur } & mtDNA & & 100 & & & \\
\hline & Blood group + protein & 13 & $94.71 \pm 3.99$ & $3.40 \pm 1.95$ & $1.89 \pm 3.99$ & 0.9814 \\
\hline & Y-chromosome & & 94.3 & & 5.7 & \\
\hline
\end{tabular}


TABLE 3 (Continued)

\begin{tabular}{|c|c|c|c|c|c|c|}
\hline \multirow{2}{*}{ Tribes } & \multirow{2}{*}{ Systems } & \multirow{2}{*}{ No. systems } & \multicolumn{3}{|c|}{ Parental contribution } & \multirow{2}{*}{$\mathbf{R}^{2}$} \\
\hline & & & Amerindian & African & European & \\
\hline \multirow[t]{3}{*}{ Wayampi } & mtDNA & & 100 & & & \\
\hline & Blood group + protein & 20 & $83.76 \pm 8.68$ & & $16.24 \pm 8.68$ & 0.8306 \\
\hline & Y-chromosome & & 100 & & & \\
\hline \multirow[t]{3}{*}{ Mean } & mtDNA & & 98.62 & 1.38 & 0 & \\
\hline & Blood group + protein & & $89.76 \pm 3.75$ & $0.68 \pm 0.39$ & $9.56 \pm 3.75$ & 0.9499 \\
\hline & Y-chromosome & & 95.06 & 1.88 & 3.06 & \\
\hline
\end{tabular}




\section{APPENDIX}

List of African and Afro-American populations examined for HVS-I considered in the admixture analysis

\begin{tabular}{|c|c|c|c|c|}
\hline Continent & Country & Populations & $\begin{array}{l}\text { No. } \\
\text { individuals }\end{array}$ & $\mathrm{L} 2 \mathrm{~d} 2$ \\
\hline \multirow[t]{23}{*}{ Africa } & Cameroon $^{\mathrm{a}}$ & Hide & 23 & 1 \\
\hline & & Kotoko & 32 & \\
\hline & & Mafa & 18 & \\
\hline & & Masa & 31 & \\
\hline & Cameroon $^{\mathrm{b}}$ & Daba & 20 & \\
\hline & & Fali & 41 & 1 \\
\hline & & Fulbe & 34 & \\
\hline & & Mandar & 37 & 2 \\
\hline & & Uldeme & 39 & \\
\hline & & Podokwo & 20 & 1 \\
\hline & & Tali & 25 & \\
\hline & & Tupuri & 28 & \\
\hline & & Bakaka & 50 & \\
\hline & & Bamike & 48 & \\
\hline & & Bassa & 46 & \\
\hline & & Ewondo & 53 & \\
\hline & Cabo Verde ${ }^{\mathrm{c}}$ & Archipelago of Cabo Verde & 292 & 1 \\
\hline & Guinea-Bissau $^{\mathrm{d}}$ & Balanta & 62 & 2 \\
\hline & & Beafada & 19 & \\
\hline & & Bijago & 22 & \\
\hline & & Djola & 18 & \\
\hline & & Fula & 38 & \\
\hline & & Futa-Fula & 19 & \\
\hline
\end{tabular}


(Continued)

\begin{tabular}{|c|c|c|c|c|c|}
\hline Continent & Country & Populations & & $\begin{array}{l}\text { No. } \\
\text { individuals }\end{array}$ & $\mathrm{L} 2 \mathrm{~d} 2$ \\
\hline & & Fula-Preto (Peul) & & 19 & \\
\hline & & Mancanha & & 19 & \\
\hline & & Mandenka & & 30 & 1 \\
\hline & & Manjaco & & 27 & \\
\hline & & Mansonca & & 18 & \\
\hline & & Nalu & & 26 & \\
\hline & & Papel & & 23 & \\
\hline & Senegal $^{\mathrm{e}}$ & Mandenka & & 119 & 1 \\
\hline & São Tomé/Bioko ${ }^{\mathrm{f}}$ & Bubi & & 45 & \\
\hline & & São Tomé & & 50 & \\
\hline & São Tomé and Principe ${ }^{\mathrm{g}}$ & Angolares & & 30 & \\
\hline & & Forros & & 35 & \\
\hline & & Tongas & & 38 & 1 \\
\hline & Sierra Leone ${ }^{\mathrm{h}}$ & Mende & & 59 & 3 \\
\hline & & Temne & & 121 & 4 \\
\hline & & Loko & & 29 & 1 \\
\hline & & Limba & & 67 & 1 \\
\hline & Congo $^{\mathrm{i}}$ & Mbuti & & 20 & \\
\hline & Nigeria/Niger/Mali ${ }^{\mathrm{i}}$ & Songhai & & 10 & \\
\hline & & Tuareg & & 23 & \\
\hline & Nigeria $^{\mathrm{i}}$ & Yoruba & & 34 & \\
\hline & $\begin{array}{l}\text { Nigeria, Niger, Benin, } \\
\text { Cameroun, Burkina Faso }\end{array}$ & Fulbe & & 60 & \\
\hline & Nigeria/Niger ${ }^{\mathrm{i}}$ & Hausa & & 20 & \\
\hline & & Kanuri & & 14 & 1 \\
\hline & & & Total & 1951 & 21 \\
\hline \multicolumn{6}{|l|}{ America } \\
\hline & Colombia $^{\mathrm{j}}$ & Choco & & 49 & \\
\hline & Honduras $^{\mathrm{j}}$ & Garifune & & 44 & \\
\hline & & Afro-Americans ${ }^{\mathrm{k}}$ & & 481 & \\
\hline
\end{tabular}


(Continued)

\begin{tabular}{|c|c|c|c|c|c|}
\hline Continent & Country & Populations & & $\begin{array}{l}\text { No. } \\
\text { individuals }\end{array}$ & $\mathrm{L} 2 \mathrm{~d} 2$ \\
\hline \multicolumn{2}{|r|}{ U. S. A. ${ }^{1}$} & Afro-Americans & & 1943 & 26 \\
\hline \multirow{3}{*}{\multicolumn{2}{|c|}{ Brazil $^{\mathrm{m}, \mathrm{n}}$}} & Curiaú & & 58 & \\
\hline & & São Paulo & & 120 & 1 \\
\hline & & & Total & 2695 & 27 \\
\hline
\end{tabular}

${ }^{\mathrm{a}}$ Černý et al. (2004); ${ }^{\mathrm{b}}$ Coia et al. (2005); ${ }^{\mathrm{c}} \mathrm{Brehm}$ et al. (2002); ${ }^{\mathrm{d}}$ Rosa et al. (2004); ${ }^{\mathrm{e}} \mathrm{Graven}$ et al. (1995); ${ }^{\mathrm{P}}$ Mateu et al. (1997); ${ }^{\mathrm{g}}$ Trovoada et al. (2004); ${ }^{\mathrm{h}}$ Jackson et al. (2005); ${ }^{\mathrm{i}}$ Watson et al.,

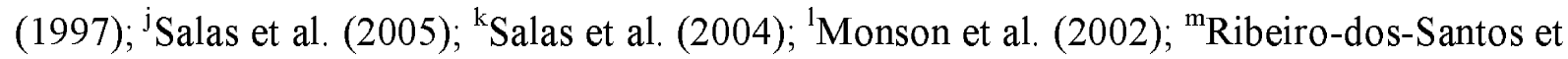
al. (2002); ${ }^{\mathrm{n}}$ Gonçalves et al. (2008). 


\section{LITTERATURE CITED IN APPENDIX}

Brehm A, Pereira L, Bandelt HJ, Prata MJ, Amorim A. 2002. Mitochondrial portrait of the Cabo Verde archipelago: the Senegambian outpost of Atlantic slave trade. Ann Hum Genet 66:49-60.

Černý V, Hajek M, Cmejla R, Bruzek J, Brdicka R. 2004. mtDNA sequences of Chadicspeaking populations from northern Cameroon suggest their affinities with eastern Africa. Ann Hum Biol 31:554-569.

Coia V, Destro-Bisol G, Verginelli F, Battaggia C, Boschi I, Cruciani F, Spedini G, Comas D, Calafell F. 2005. MtDNA variation in North Cameroon: lack of Asian lineages and implications for back migration from Asia to sub-Saharan Africa. Am J Phys Anthropol 128:678-681.

Gonçalves VF, Carvalho CM, Bortolini MC, Bydlowski SP, Pena SDJ. 2008. The phylogeography of African Brazilians. Hum Hered 65:23-32.

Graven L, Passarino G, Semino O, Boursot P, Santachiara-Benerecetti S, Langaney A, Excoffier L. 1995. Evolutionary correlation between control region sequence and restriction polymorphisms in the mitochondrial genome of a large Senegalese Mandenka sample. Mol Biol Evol 12:334-345.

Jackson BA, Wilson JL, Kirbah S, Sidney SS, Rosenberger J, Bassie L, Alie JA, McLean DC, Garvey WT, Ely B. 2005. Mitochondrial DNA genetic diversity among four ethnic groups in Sierra Leone. Am J Phys Anthropol 128:156-163.

Mateu E, Comas D, Calafell F, Perez-Lezaun A, Abade A, Bertranpetit J. 1997. A tale of two islands: population history and mitochondrial DNA sequence variation of Bioko and São Tomé, Gulf of Guinea. Ann Hum Genet 61:507-518. 
Monson KL, Miller KWP, Wilson MR, DiZinno JA, Budowle B. 2002. The mtDNA Population Database: an integrated software and database resource for forensic comparison. Forensic Science Communications 4:2.

Ribeiro-dos-Santos AK, Pereira JM, Lobato MR, Carvalho BM, Guerreiro JF, Santos SEB. 2002. Dissimilarities in the process of formation of Curiau, a semi-isolated AfroBrazilian population of the Amazon region. Am J Hum Biol 14:440-447.

Rosa A, Brehm A, Kivisild T, Metspalu E, Villems R. 2004. MtDNA profile of West Africa Guineans: towards a better understanding of the Senegambia region. Ann Hum Genet 68:340-352.

Salas A, Richards M, Lareu MV, Scozzari R, Coppa A, Torroni A, Macaulay V, Carracedo A. 2004. The African diaspora: mitochondrial DNA and the Atlantic slave trade. Am J Hum Genet 74:454-465.

Salas A, Carracedo A, Richards M, Macaulay V. 2005. Charting the ancestry of African Americans. Am J Hum Genet 77:676-680.

Trovoada MJ, Pereira L, Gusmao L, Abade A, Amorim A, Prata MJ. 2004. Pattern of mtDNA variation in three populations from Sao Tome e Principe. Ann Hum Genet 68:40-54.

Watson E, Forster P, Richards M, Bandelt HJ. 1997. Mitochondrial footprints of human expansions in Africa. Am J Hum Genet 61:691-704. 
Figure 1

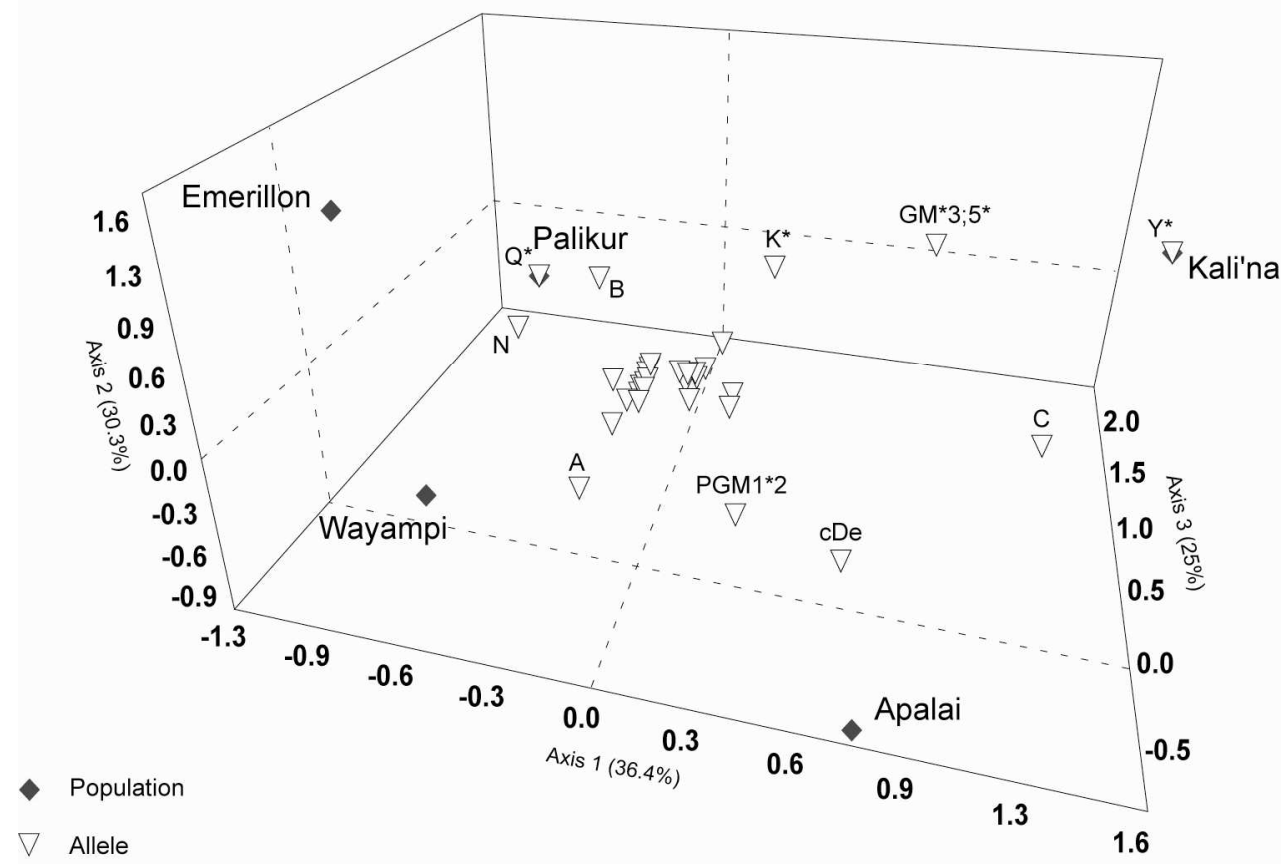

